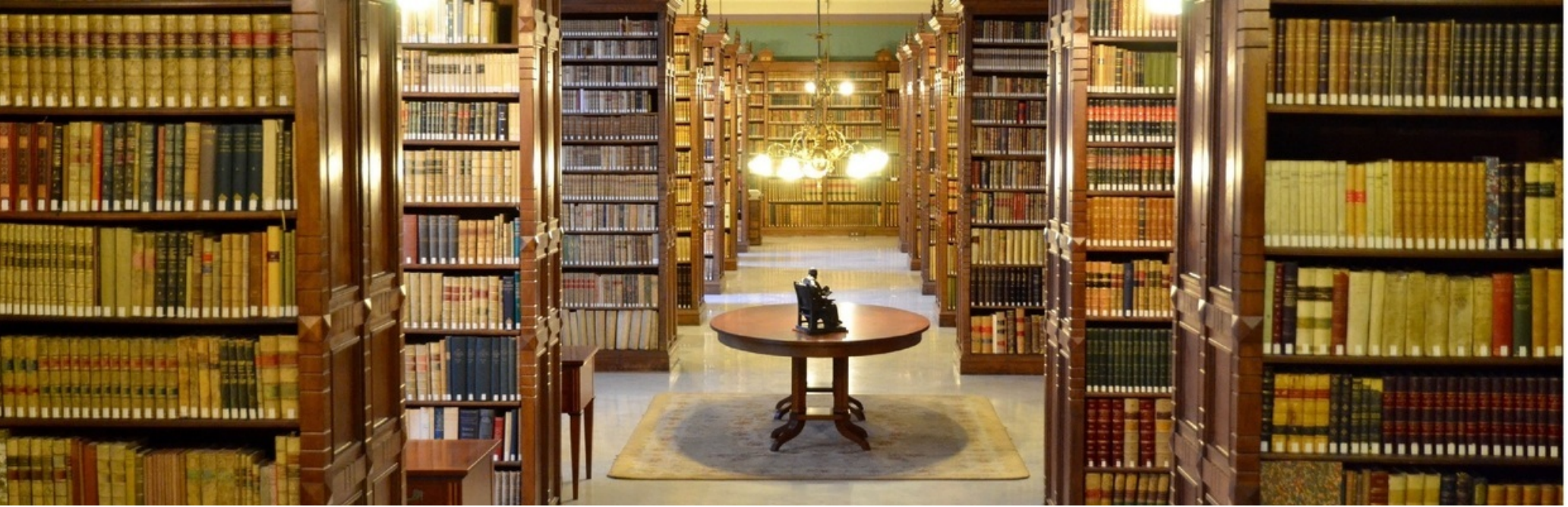

\title{
Editorial Volume 8, Issue 5
}

$\begin{aligned} \text { Authors: } & \text { Stephan Seiler } \\ \text { Submitted: } & \text { 4. January } 2022 \\ \text { Published: } & \text { 4. January } 2022 \\ \text { Volume: } & 9 \\ \text { Issue: } & 1 \\ \text { Affiliation: } & \text { Josha Journal. Freiburg, Germany } \\ \text { Languages: } & \text { English } \\ \text { Keywords: } & \text { Editorial, JOSHA Journal, } 2022 \text { Volume 8, Issue } 5 \\ \text { Categories: } & \text { News and Views } \\ \text { DOI: } & \text { 10.17160/josha.9.1.797 }\end{aligned}$

Abstract:

The past year was again strongly influenced by the pandemic. But while events with attendance had to be cancelled again to a large extent, we were able to continue the digital work on our journal. In addition to Covid-19, other topics dominate the current discussion in society, business and politics. These topics also find their way into the journal, for example, an article by Astrid Heinl is about more women in leadership positions. For those who want to leave the troubles of the pandemic behind and wander a little further afield, there is the opportunity to read the tribute to Bordeaux. It comes from the president of the International Academy of Sciences, Humanities and Arts Gerhard Steinmann. Now we hope you enjoy reading the journal. We have just started our 9th Volume and are full of energy and positivity for the upcoming year. The whole Journal-Team wishes you a Happy New Year 2022!

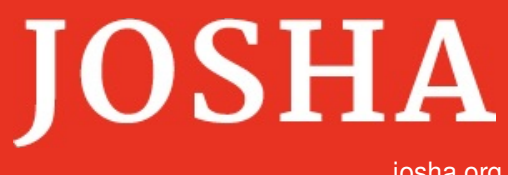

josha.org
Journal of Science,

Humanities and Arts

JOSHA is a service that helps scholars, researchers, and students discover, use, and build upon a wide range of content 


\section{Editorial}

Volume 9, Issue 1

\section{Happy new year 2022}

Dear Josha-Journal readers,

The past year was again strongly influenced by the pandemic. But while events with attendance had to be cancelled again to a large extent, we were able to continue the digital work on our journal. In addition to Covid-19, other topics dominate the current discussion in society, business and politics. These topics also find their way into the journal, for example, an article by Astrid Heinl is about more women in leadership positions.

For those who want to leave the troubles of the pandemic behind and wander a little further afield, there is the opportunity to read the tribute to Bordeaux. It comes from the president of the International Academy of Sciences, Humanities and Arts Gerhard Steinmann.

Now we hope you enjoy reading the journal.

The whole Journal-Team wishes you a Happy New Year 2022!

\section{Dr. Stephan Seiler}

Vice President

International Academy of Sciences, Humanities and Arts

Volume 9, Issue 1

Thomas Würtenberger: Zur Reform der staatlichen Anerkennung und der institutionellen Akkreditierung privater Hochschulen - On the Reform of State Recognition and institutional Accreditation of private higher Education Institutions

Usman Al-amin: Tooth Dyeing Tradition among the Kanuri Speaking People of Borno, Nigeria José Barletta: Zero Sero

Astrid Heinl: Mehr Frauen in Führungspositionen - More women in Leadership Roles

Silvia Gonzalez, Daniela Celia Graiño, Yessica Milena Flórez Bautista et al.: Neuroeducational Intervention in Children with Intellectual Disabilities - Intervención Neuroeducativa en Niños con Discapacidad Intelectual

Gerhard Steinmann: To Bordeaux - With Love. A Homage in Three Languages

Giovanni Corvino: Review: W. A. SCHABAS, The Customary International Law of Human Rights, Oxford Bard Bajçinovci: A Conceptual Approach for a Multifunctional Center in Prishtina 